\title{
The Effects of Macroeconomic Factors on Bank Loan Interest Rates in Turkey
}

\author{
Münevvere Yıldız ${ }^{\mathrm{a}^{*}}$ \\ ${ }^{\text {a} A f y o n ~ K o c a t e p e ~ U n i v e r s i t y, ~ S c h o o l ~ o f ~ A p p l i e d ~ S c i e n c e s, ~ T u r k e y ~}$
}

\begin{tabular}{|c|c|}
\hline A B S T R A C T & ARTICLE INFO \\
\hline $\begin{array}{l}\text { The purpose of the study to reveal how interest rates on loans offered to } \\
\text { consumers by banks in Turkey are affected by macroeconomic factors. For } \\
\text { this purpose, the personal loan interest rate is considered as the consumer } \\
\text { loan interest rate, mortgage loan interest rate and vehicle loan interest rate. } \\
\text { Macroeconomic factors, inflation, gold, exchange rate and money supply } \\
\text { are included in the analysis. Three models have been established using } \\
\text { monthly data for the period January 2009-June 2020. Firstly, cointegration } \\
\text { test was applied to the models and it was determined that there is at least } \\
\text { one cointegration relationship in each model. Long-term estimation results } \\
\text { for the models are obtained by using the FMOLS method. In general, it was } \\
\text { observed that the increase in the exchange rate tended to increase the bank } \\
\text { loan interest rates, while the increase in the money supply lowered the bank } \\
\text { loan interest rates. As a result of the causality analysis, bidirectional } \\
\text { causality relationship from consumer loan interest rate to money supply and } \\
\text { inflation, unidirectional causality from interest rate to gold price, } \\
\text { unidirectional causality relationship from exchange rate to interest rate was } \\
\text { determined. Unidirectional causality relationship from mortgage loan } \\
\text { interest rate to money supply, unidirectional causality from exchange rate } \\
\text { to interest rate was found. While it was determined that there is a } \\
\text { bidirectional causality relationship between vehicle loan interest rate and } \\
\text { money supply, gold price and inflation. It is expected that these results may } \\
\text { guide banks and policymakers to determine interest rate policies. }\end{array}$ & $\begin{array}{l}\text { Keywords: } \\
\text { Bank Loans Interest Rate, } \\
\text { Macroeconomic Factors, Co- } \\
\text { intregration, FMOLS, Causality } \\
\text { *Corresponding author: } \\
\text { munevvereyildiz@aku.edu.tr } \\
\text { (Münevvere Y1ldı) } \\
\\
\text { Article history: } \\
\text { Received } 10122020 \\
\text { Revised } 21122020 \\
\text { Accepted } 23122020\end{array}$ \\
\hline
\end{tabular}

\section{INTRODUCTION}

Banks are organizations that aim for profit and have an important place in the financial system. Any positive or negative fluctuations in the banking sector, which is an important part of the economic system, rapidly affect both the market and the sector. While banks, as commercial enterprises, continue their activities for profit, there are many functions they undertake as part of the economic system. These functions can be ordered as financial intermediation, creating liquidity, evaluating and monitoring credit demanders, solving asymmetric information problems, increasing the effectiveness of monetary policies, affecting economic stability, benefiting from economies of scale and scope, increasing the efficiency of payment systems, funding foreign trade and encouraging exports (Yağcılar Göçmen, 2011). 
Personal loans offered by banks have an important role in satisfying the needs of individuals in society immediately. At this point, while people are taking loans from banks, if the other conditions are the same, the low-interest rate is preferred. From the perspective of banks, it is to increase the number of people using loans by lowering interest rates (Ibicioglu and Karan, 2009). Changes in personal interest rates will increase the consumption expenditures of individuals, and this will have a positive effect on economic growth. In addition, as the change in interest rates affects the economic balances, it is an important tool that can be used in eliminating the recession in the market in line with the purpose of monetary policies.

Based on the importance of the banking sector in the economy, the aim of the study is to establish three different models for personal loan interest rates, which are classified as consumer loans, mortgage loans, and vehicle loans, to observe how interest rates are affected by economic data and to make comparisons of models. The results to be obtained here about inflation, exchange rate, gold and money supply forecasts will be useful for banks' loan interest policies and decisions. On the other hand, it has been observed that most of the studies in the literature have been studied with a limited number of variables, especially for loan interest rates in banks. Very few of these studies have been researched by classifying personal loans. The large number of variables used distinguishes the study from other studies in the literature, and it is considered to add innovation to the literature.

In the first part of the study, information about the studies in the literature is given. In the second part, the methods used are explained and in the third part the data set is introduced. In the fourth chapter, the results obtained with the applications are presented in tables. In the last part of the study, findings and interpretation of the results, suggestions for the development of the study are included.

\section{LITERATURE REVIEW}

There are various interest rates in the economic structure. There are many studies in the literature that research on interest rates. However, in line with the purpose of the study, in this section, studies that use interest rates in the banking sector and are specific to the banking sector are compiled.

In most of these studies, the answer to the question of what kind of relationship exists between bank loans and economic growth has been sought. Some studies using data from Turkey as follows; Kar and Pentecost (2000), Güven (2002), Yılmaz et al. (2007), Altunç (2008), Ceylan and Durkaya (2010), Tuna and Bektaş (2013), Mercan (2013), Vurur and Özen (2013), Sever and Han (2015), Turgut and Ertay (2016), Torun and Karanfil (2016), Pehlivan et al. (2017), Apaydın (2018). According to the results obtained from these studies, it is noteworthy that there is no consensus on the relationship between bank loans and economic growth. On the other hand, the relationship between bank loans and economic growth has also been a matter of concern for different countries with different development levels. Studies examining this relationship in a wide geography are Levine and Zervos (1998), Beck and Levine 
(2004), Mccaig and Stengos (2005), Pagano and Pica (2012), Duican and Pop (2015), Fufa and Kim (2017).

Another factor that is curious about its relationship with bank loans is inflation. Some of the studies examining the relationship between bank loans and inflation are Arslan and Yapraklı (2008), Akçacı and Method (2011), Peker and Canbazoğlu (2011), Korkmaz (2015), Kilıç and Torun (2018).

In studies involving various interest rates and macroeconomic variables applied by banks, it was generally carried out to examine the relationship between interest rate and inflation, exchange rate and money supply.

Ibicioglu and Karan (2009) investigated the effects of interest rates on personal loans in their studies covering the period 2004-2009. In the study, personal loans are the dependent variables, interest rate, ISE national index and consumer confidence index as independent variables. According to the causality analysis results of the study, unidirectional causality relationships from personal loan interest rate and ISE index to loan volume were found. In the regression model applied, it was seen that only the lagged values of interest rates on personal loans are significant.

Aytaç ve Sağlam (2014), examined the relationship between public deficits in Turkey, public debt, inflation, growth rate, and deposit interest rates with the VAR approach and causality using data from the 1980-2012 period. Accordingly, it has been concluded that interest rates affect public deficits through inflation. It has also been determined that the interest rate is the Granger cause of inflation.

Tanrı̈ver and Yamak's (2015) study carried out to test the Gibson paradox for Turkey's economy, have used the consumer price index and nominal interest rate as the variable. As a result of the application made with the cointegration analysis based on the ARDL Bound Test approach, the existence of a longterm relationship from the general price level to the nominal interest rate and the existence of Gibson paradox are accepted.

Another study examining the nominal interest rate and consumer price index was conducted by Tunali and Erönal (2016). Studies using data in period 2003-2014 in Turkey relationship between two variables is demonstrated by taking into account the structural break Gregory Hansen test. According to the findings, there is a long-term relationship between nominal interest rate and inflation. The validity of the Fisher hypothesis is stated in the relevant period for Turkey.

In the study, the non-parametric regression method is used to investigate the impact of inflation on the weighted average exchange rate using Turkey's 2010-2015 period data. The findings reveal the existence of a positive and statistically significant relationship deposit interest rate with and exchange rate and inflation (Ekinci et.al, 2016).

Obeng and Sakyi (2017) examined the relationship between the interest rate spread and macroeconomic variables in Ghana in the period 1980-2013 using the ARDL boundary test approach and the Vector Error Correction model. As a result of the study, it was seen that the volatility of the exchange rate, fiscal deficit, economic growth, and commercial bank public borrowing increased the interest rate margin in the long and short term.

PAGE 72| Journal of Corporate Governance, Insurance, and Risk Management | 2020, VOL. 7, Series. 2 
In their study, Akıncı and Y1lmaz (2016) determined the relationship between the deposit interest rate and six different variables with Dynamic Least Squares (DOLS) analysis. Using the data for the period 1980-2012, it has been determined that inflation, current account balance, foreign debt service, money supply, exchange rate and economic growth are statistically significant on the interest rate. While the effect of money supply on the interest rate is negative, other variables have a positive effect.

Kartal (2019) aimed to identify the factors affecting the commercial loan interest rates in Turkey. The effects of 8 different variables were observed using quarterly data for the period 2006-2018 and the Multivariate Adaptive Regression Splines (MARS) method. Deposit interest, foreign trade balance, central bank reserve, dollar rate, M2 and inflation variables are effective on the interest rate.

The purpose of the study, in which commercial bank loan interest rate and producer price index, consumer price index, exchange rate and CBRT overnight interest rates are used, is to determine which of the interest rate and exchange rate is more effective on inflation. For this purpose, cointegration and causality analysis was conducted in the study, in which monthly data from July 2016-June 2019 were used. FMOLS results show that the change in the exchange rate is more than the producer price index on bank interest rates. Also, a relationship between the consumer price index and interest rates couldn't be determined (Ozen et al., 2020).

When the literature is examined, the bank loan interest rate has been used as the deposit interest rate, common the personal loan interest rate or the commercial loan interest rate in most of the studies. This situation in the study will contribute to the issue from a sectoral perspective.

\section{METHODOLOGY}

The analysis will be carried out using three methods. First, the long-term relationship between variables will be determined using the cointegration test. Afterward, the direction and size of long-term relationships of variables will be tested by the FMOLS method. Finally, the causality relationship between variables will be studied by the causality test. The methods to be used in the study are briefly explained below.

\subsection{Co-Integration}

Cointegration techniques are argued to be suitable for analyzing long-term relationship among the variables. There are some cointegration techniques in literatüre and Johansen cointegration test is one of them. This approach estimates the association between non-stationary series in the long-term by employing maximum probability procedure forecasting the numbers and parameters of cointegration relationship (Asteriou and Hall, 2011). Johansen (1988) and Johansen and Juselius (1990) developed the test method. This cointegration test follow the VAR approach to examine the long-term relationship among variables. To use Johansen's method, we need to turn the VAR of the form; 


$$
y_{t}=\beta_{1} y_{t-1}+\beta_{2} y_{t-2}+\cdots+\beta_{k} y_{t-k}+u_{t}
$$

into a VECM, which can be written as

$$
\Delta y_{t}=\Pi y_{t-k}+\Gamma_{1} \Delta y_{t-1}+\Gamma_{2} \Delta y_{t-2}+\cdots+\Gamma_{k-1} \Delta y_{t-(k-1)}+u_{t}
$$

$\Pi$ is long run coefficient matrix since all the $\Delta y_{t-i}=0$. The test for cointegration between the y's is calculated by looking at the rank of the $\Pi$ matrix via its eigenvalues. The number of cointegrating vectors (r) is determined according to trace and maximum eigenvalue test statistics. The test statistics for cointegration are formulated as

$$
\lambda_{\text {trace }}(r)=-T \sum_{i=r+1}^{g} \ln \left(1-\hat{\lambda}_{i}\right)
$$

and

$$
\lambda_{\text {trace }}(r)=-T \sum_{i=r+1}^{g} \ln \left(1-\hat{\lambda}_{i}\right)
$$

where $\hat{\lambda}_{i}$ is the estimated value for the $i$ th ordered eigenvalue from the $\Pi$ matrix (Brooks, 2002).

\subsection{Long Run Coefficient with FMOLS}

Fully Modified Ordinary Least Square (FMOLS) estimator, proposed by Phillips and Hansen (1990), uses the preliminary estimates of symmetric and one-sided long-run covariance matrices of residuals. FMOLS estimator eliminate diagnostic problems in standard estimators. FMOLS models are categories of multiple time series models that directly estimate the long run effect of the independent variables on the dependent variables after correcting for the endogeneity problem in the time series. If FMOLS method developed by Phillips and Hansen (1990) is expressed as an $n+1$ dimensional time series vector;

$$
Y_{t}=X_{t}^{\prime} \beta+D_{1 t}^{\prime} \gamma_{1}+u_{1 t}
$$

where $D_{t}=\left(D_{1 t}^{\prime}, D_{2 t}^{\prime}\right)^{\prime}$ denotes deterministic trend variables. After the long-term covariance matrices calculated from residuals and a series of operations are made, the FMOLS estimator as follows,

$$
\hat{\theta}_{F M O L S}=\left[\begin{array}{l}
\hat{\beta} \\
\hat{\gamma}_{1}
\end{array}\right]=\left(\sum_{t=2}^{T} Z_{t} Z_{t}^{\prime}\right)^{-1}\left(\sum_{t=2}^{T} Z_{t} y_{t}^{+}-T\left[\begin{array}{c}
\hat{\lambda}_{12}^{+} \\
0
\end{array}\right]\right)
$$

where $Z_{t}=\left(X_{t}^{\prime}, D_{t}^{\prime}\right)^{\prime}$. The Fully Modified Ordinary Least Square estimator in Equation (6) is asymptotically unbiased and efficient.

\subsection{Causality}

Granger (1969) developed a relatively simple test that describes causality between variables. According to Granger, if the prediction of $\mathrm{Y}$ is more successful when the past values of $\mathrm{X}$ are used than when the 
past values of $\mathrm{X}$ are not used (other terms are not changed), $\mathrm{X}$ is the Granger cause of $\mathrm{Y}$. The following two models are used to perform the test.

$$
\begin{aligned}
& Y_{i}=\beta_{0}+\sum_{n=1}^{i} \beta_{i} Y_{t-i}+\sum_{n=1}^{i} \gamma_{i} X_{t-i}+\varepsilon \\
& X_{i}=\beta_{0}+\sum_{n=1}^{i} \beta_{i} X_{t-i}+\sum_{n=1}^{i} \gamma_{i} Y_{t-i}+\varepsilon
\end{aligned}
$$

Here $i$ indicates lag lenght and $\beta_{i}$ and $\gamma_{i}$ are predicted parameters. The Granger test is based on comparing the $\mathrm{F}$ statistics of the models by using two different models to explain the $\mathrm{Y}$ variable. Equation (7) indicates the causality from $\mathrm{X}$ to $\mathrm{Y}$, Equation (8) indicates the causality from $\mathrm{Y}$ to $\mathrm{X}$.

\section{DATA}

The aim of the study is to reveal how the interest rates on loans offered to consumers by banks are affected by macroeconomic data. In the study, consumer loan interest rate, mortgage loan interest rate, and vehicle loan interest rate were used as dependent variables. Consumer Price Index, exchange rate, gold price and money supply were included in the study as independent variables. Monthly data for the period January 2009-June 2020 were used in the analyzes. All of the data was obtained from the CBRT database and analyzes were carried out by taking the natural logarithm of all variables. The variables used in the study and their abbreviations are expressed in Table 1.

Table 1: Variables

\begin{tabular}{ll}
\hline Variable & Abbreviation \\
\hline Interest rate of consumer credits & rate $_{\text {consumer }}$ \\
\hline Interest rate of mortgage credits & rate $_{\text {mortgage }}$ \\
\hline Interest rate of vehicle credits & rate $_{\text {vehicle }}$ \\
\hline Consumer price index & cpi \\
\hline Gold price & gold \\
\hline Exchange rate & usd \\
\hline Money supply & M2 \\
\hline
\end{tabular}

The stationarity levels of the series used in econometric applications are very important in terms of both determining the method to be used and obtaining appropriate results. For this purpose, the Augmented Dickey-Fuller Unit Root Test (ADF) (Dickey and Fuller, 1979) and Phillips-Perron Unit Root Test (PP) (Phillips and Perron, 1988) were used to perform stationarity analysis of the series.

\begin{tabular}{|c|c|c|c|c|c|c|}
\hline \multirow[b]{2}{*}{ Series } & \multirow[b]{2}{*}{ Level } & \multicolumn{2}{|c|}{$\begin{array}{c}\text { Augmented Dickey- } \\
\text { Fuller (ADF) Test }\end{array}$} & \multicolumn{2}{|c|}{$\begin{array}{c}\text { Phillips-Perron (PP) } \\
\text { Test }\end{array}$} & \multirow[b]{2}{*}{$\begin{array}{c}\text { Stationary } \\
\text { Level }\end{array}$} \\
\hline & & Intercept & $\begin{array}{l}\text { Trend+ } \\
\text { Intercept }\end{array}$ & Intercept & $\begin{array}{l}\text { Trend+ } \\
\text { Intercept }\end{array}$ & \\
\hline \multirow{3}{*}{ rate $_{\text {consumer }}$} & Level & $\begin{array}{l}-2.542490 \\
(0.1078)\end{array}$ & $\begin{array}{l}-2.880198 \\
(0.1723)\end{array}$ & $\begin{array}{l}-2.191921 \\
(0.2102)\end{array}$ & $\begin{array}{l}-2.410835 \\
(0.3723)\end{array}$ & \multirow[t]{3}{*}{$\mathbf{I}(\mathbf{1})$} \\
\hline & Difference & $\begin{array}{l}-6.370017 \\
(0.0000)\end{array}$ & $\begin{array}{l}-6.337326 \\
(0.0000)\end{array}$ & $\begin{array}{l}-7.058171 \\
(0.0000)\end{array}$ & $\begin{array}{l}-7.024845 \\
(0.0000)\end{array}$ & \\
\hline & Level & -2.814540 & -2.923970 & -2.403508 & -2.529910 & \\
\hline
\end{tabular}

Table 2: Unit root test results

PAGE 75| Journal of Corporate Governance, Insurance, and Risk Management | 2020, VOL. 7, Series. 2 


\begin{tabular}{|c|c|c|c|c|c|c|}
\hline \multirow[t]{2}{*}{ rate $_{\text {mortgage }}$} & & $(0.0589)$ & $(0.1583)$ & $(0.1427)$ & $(0.3134)$ & \multirow[t]{2}{*}{ I(1) } \\
\hline & Difference & $\begin{array}{l}-6.737619 \\
(0.0000)\end{array}$ & $\begin{array}{l}-6.696372 \\
(0.0000)\end{array}$ & $\begin{array}{l}-6.418531 \\
(0.0000)\end{array}$ & $\begin{array}{l}-6.373356 \\
(0.0000)\end{array}$ & \\
\hline \multirow{2}{*}{ rate $_{\text {vehicle }}$} & Level & $\begin{array}{l}-2.137681 \\
(0.2304)\end{array}$ & $\begin{array}{l}-2.560611 \\
(0.2991)\end{array}$ & $\begin{array}{l}-2.071067 \\
(0.2567)\end{array}$ & $\begin{array}{l}-2.538436 \\
(0.3094)\end{array}$ & \multirow[t]{2}{*}{ I(1) } \\
\hline & Difference & $\begin{array}{l}-7.613555 \\
(0.0000)\end{array}$ & $\begin{array}{l}-7.576543 \\
(0.0000)\end{array}$ & $\begin{array}{l}-7.650351 \\
(0.0000)\end{array}$ & $\begin{array}{l}-7.614070 \\
(0.0000)\end{array}$ & \\
\hline \multirow[t]{2}{*}{ usd } & Level & $\begin{array}{l}1.305430 \\
(0.9986)\end{array}$ & $\begin{array}{l}-2.905101 \\
(0.1643)\end{array}$ & $\begin{array}{l}1.139190 \\
(0.9977)\end{array}$ & $\begin{array}{l}-2.335854 \\
(0.4116)\end{array}$ & \multirow[t]{2}{*}{ I(1) } \\
\hline & Difference & $\begin{array}{l}-8.666025 \\
(0.0000)\end{array}$ & $\begin{array}{l}-9.030514 \\
(0.0000)\end{array}$ & $\begin{array}{l}-7.836896 \\
(0.0000)\end{array}$ & $\begin{array}{l}-7.872256 \\
(0.0000)\end{array}$ & \\
\hline \multirow[t]{2}{*}{ срі } & Level & $\begin{array}{l}2.443518 \\
(1.0000)\end{array}$ & $\begin{array}{l}-0.477718 \\
(0.9835)\end{array}$ & $\begin{array}{l}2.497147 \\
(1.0000)\end{array}$ & $\begin{array}{l}-0.780828 \\
(0.9641)\end{array}$ & \multirow[t]{2}{*}{ I(1) } \\
\hline & Difference & $\begin{array}{l}-6.624796 \\
(0.0000)\end{array}$ & $\begin{array}{l}-7.229525 \\
(0.0000)\end{array}$ & $\begin{array}{l}-8.801683 \\
(0.0000)\end{array}$ & $\begin{array}{l}-9.077803 \\
(0.0000)\end{array}$ & \\
\hline \multirow[t]{2}{*}{ gold } & Level & $\begin{array}{l}0.850704 \\
(0.9946)\end{array}$ & $\begin{array}{l}-0.611220 \\
(0.9766)\end{array}$ & $\begin{array}{l}0.869588 \\
(0.9949)\end{array}$ & $\begin{array}{l}-0.708674 \\
(0.9699)\end{array}$ & \multirow[t]{2}{*}{$\mathbf{I}(\mathbf{1})$} \\
\hline & Difference & $\begin{array}{l}-10.06504 \\
(0.0000)\end{array}$ & $\begin{array}{l}-10.18566 \\
(0.0000)\end{array}$ & $\begin{array}{l}-10.01092 \\
(0.0000)\end{array}$ & $\begin{array}{l}-10.13692 \\
(0.0000)\end{array}$ & \\
\hline \multirow[t]{2}{*}{ M2 } & Level & $\begin{array}{l}1.785424 \\
(0.9997)\end{array}$ & $\begin{array}{l}-0.866205 \\
(0.9559)\end{array}$ & $\begin{array}{l}2.078941 \\
(0.9999)\end{array}$ & $\begin{array}{l}-0.843233 \\
(0.9582)\end{array}$ & \multirow[t]{2}{*}{$\mathbf{I}(\mathbf{1})$} \\
\hline & Difference & $\begin{array}{l}-11.67457 \\
(0.0000)\end{array}$ & $\begin{array}{l}-11.95874 \\
(0.0000)\end{array}$ & $\begin{array}{l}-11.67458 \\
(0.0000)\end{array}$ & $\begin{array}{l}-12.00539 \\
(0.0000)\end{array}$ & \\
\hline
\end{tabular}

Note: The first of the numerical expressions written opposite the level and difference values shows the test statistics. The value in brackets shows the probability values according to the Schwarz statistical information criterion for ADF and according to the kernel method "Barlettkernel" and bandwidth "Newey West bandwith" method for PP.

When the unit root test results in Table 2 are examined, it is seen that the series have unit root in level for both unit root tests. That is, the level values of the series are not stable. On the other hand, when the first difference of the series is taken, the null hypothesis, which expresses the presence of unit root for all variables, was rejected at the $1 \%$ significance level in unit root tests. Based on these results, the econometric analysis will be carried out by considering the I (1) case of the series being stationary at the first difference.

\section{ANALYSIS RESULTS}

The Johansen Cointegration Test was conducted to investigate the existence of a long-term relationship among the variables that are stationary in difference during the application phase. In order to reveal how consumer loan interest rate, mortgage loan interest rate, and vehicle loan interest rate offered by banks are affected by macroeconomic data, three different models have been defined in the study. In these models, the interest rate of each loan is the dependent variable and macroeconomic variables are independent variables. The models used in the study are as follows.

Model-1: rate $_{\text {consumer }}=c p i+u s d+$ gold $+M 2+\varepsilon$

Model-2: rate $_{\text {mortgage }}=c p i+u s d+$ gold $+M 2+\varepsilon$

Model-3: rate $_{\text {vehicle }}=c p i+u s d+$ gold $+M 2+\varepsilon$ 


\subsection{Co-integration Relationship Results}

First of all, in order to see whether there is a long-term relationship between variables, the cointegration method developed by Johansen (1988) and Johansen \& Juselius (1990) was used for cases where all variables are stationary at the same level. All variables included in the analysis are stationary in I (1). Before applying the cointegration test, VAR models were created for each model, then the appropriate lag length was determined according to the Akaike (AIC) information criterion. Accordingly, the most suitable lag lengths were determined as 2 for Model-1, 3 for Model-2, and 2 for Model-3. The results of Johansen (1988) and Johansen \& Juselius (1990) cointegration test performed with determined lag lengths are given in Table 3.

Table 3: Johansen co-integration results

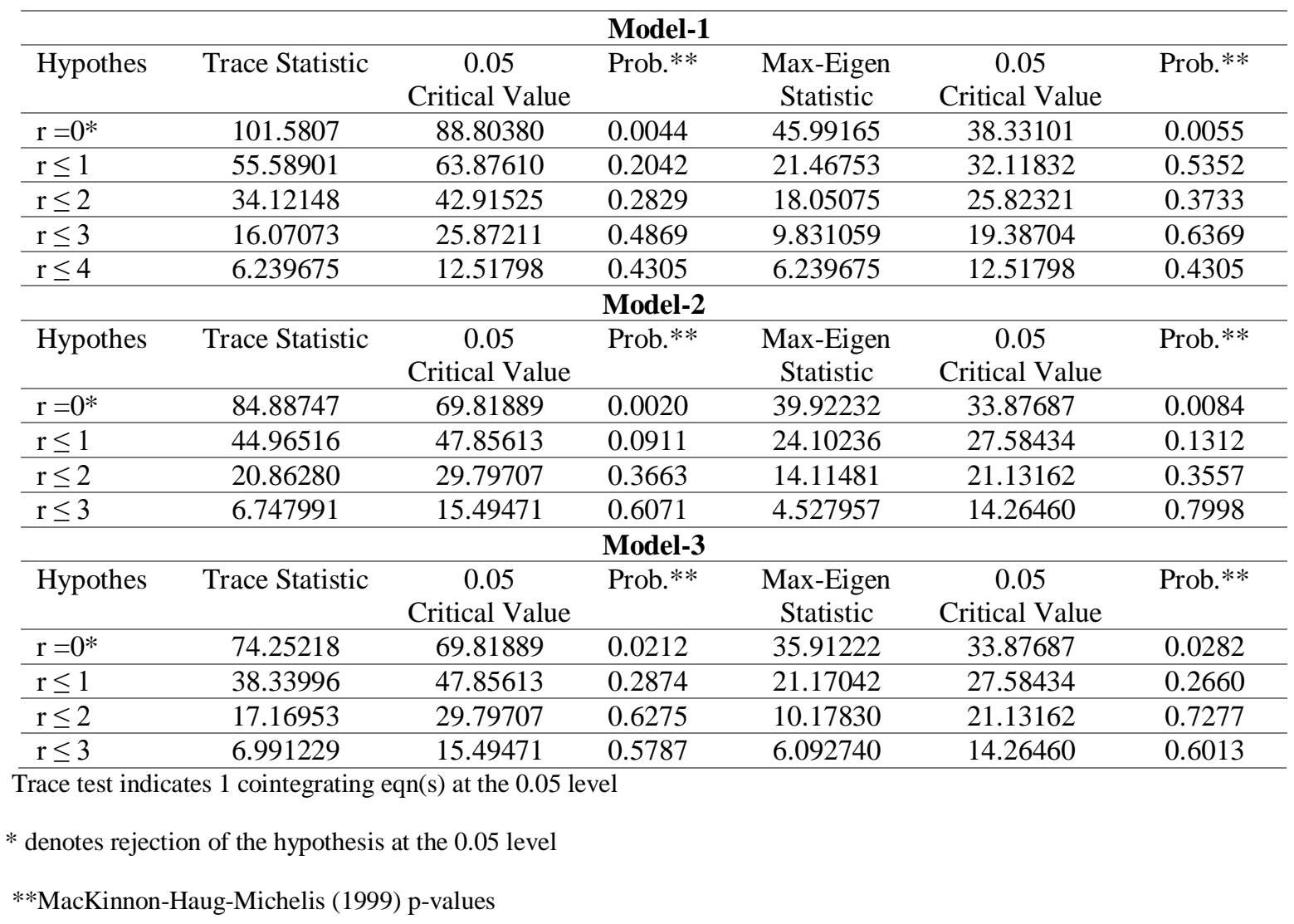

As a result of the comparison of the obtained maximum eigenvalue and trace statistics with the critical values, it is seen that there is at least 1 cointegration vector at $5 \%$ significance level in all three models. According to these results, it is possible to mention that a long-term equilibrium relationship between variables is valid during the analysis period.

\subsection{FMOLS Results}

After determining that there was at least one cointegration relationship between variables for all three models, Fully Modified Least Squares Regression (FMOLS) was used to obtain information about the direction and size of the long-term relationship between dependent variables and independent variables. 
The results of the FMOLS regression are given in Table 4 for three models in which bank loan interest rates are the dependent variable, inflation, gold, exchange rate, and money supply as independent variables.

Table 4: FMOLS regression results

\begin{tabular}{|c|c|c|c|}
\hline \multicolumn{4}{|c|}{ Dependent Variable rate concumer } \\
\hline \multicolumn{4}{|c|}{ FMOLS } \\
\hline Variables & Coefficients & t-statistics & Prob. \\
\hline $\mathrm{C}$ & 25.96401 & 5.254928 & 0.0000 \\
\hline срі & 1.035588 & 1.076700 & 0.2836 \\
\hline usd & 1.255147 & 4.344250 & 0.0000 \\
\hline gold & -0.114258 & -0.641146 & 0.5225 \\
\hline M2 & -1.422990 & -3.398446 & 0.0009 \\
\hline $\mathrm{R}^{2}=0.538595$ & Adj. $\mathrm{R}^{2}$ & .524613 & \\
\hline \multicolumn{4}{|c|}{$\begin{array}{c}\text { Dependent Variable rate } \\
\text { mortgage }\end{array}$} \\
\hline \multicolumn{4}{|c|}{ FMOLS } \\
\hline Variables & Coefficients & t-statistics & Prob. \\
\hline $\mathrm{C}$ & 27.04429 & 5.787268 & 0.0000 \\
\hline срі & 0.970869 & 1.067263 & 0.2878 \\
\hline usd & 1.427407 & 5.223616 & 0.0000 \\
\hline gold & -0.234914 & -1.393743 & 0.1657 \\
\hline M2 & -1.451961 & -3.66370 & 0.0004 \\
\hline $\mathrm{R}^{2}=0.596628$ & Adj. $\mathrm{R}^{2}$ & .584404 & \\
\hline \multicolumn{4}{|c|}{ Dependent Variable rate $_{\text {vehicle }}$} \\
\hline \multicolumn{4}{|c|}{ FMOLS } \\
\hline Variables & Coefficients & t-statistics & Prob. \\
\hline $\mathrm{C}$ & 27.76616 & 6.254569 & 0.0000 \\
\hline срі & 1.091769 & 1.263355 & 0.2087 \\
\hline usd & 1.703857 & 6.563569 & 0.0000 \\
\hline gold & -0.414303 & -2.587474 & 0.0108 \\
\hline M2 & -1.484857 & -3.946840 & 0.0001 \\
\hline $\mathrm{R}^{2}=0.727888$ & Adj. $\mathrm{R}^{2}$ & .719642 & \\
\hline
\end{tabular}

In each model, the determination coefficient $\left(\mathrm{R}^{2}\right)$ expressing how much percentage of the dependent variable explains by the independent variables in the model was found to be $54 \%$ for Model- $1,60 \%$ for Model-2, and 73\% for Model-3, respectively.

In Model-1, it is seen that the coefficients of the variables of the exchange rate and money supply are statistically significant, the increase in the exchange rate affects the consumer loan interest rate positively and the increase in the money supply negatively. In the $1 \%$ increase in the money supply, the consumer loan interest rate decreases by $1.42 \%$. On the other hand, it is seen that the $1 \%$ increase in the exchange rate increased the consumer loan interest rate by $1.26 \%$. The coefficients for gold and inflation in the model are not statistically significant.

Model-2 produced similar results to Model-1. 1\% increase in the exchange rate increases the mortgage loan interest rate by $1.43 \%$, and a $1 \%$ increase in the money supply decreases the loan interest rate by $1.45 \%$, the coefficient of both variables is statistically significant. As in Model-1, the coefficients of inflation and gold price variables are not statistically significant.

In Model-3, where vehicle loan interest rate is the dependent variable, it was observed that the coefficients of the variables of the exchange rate, gold price, and money supply were statistically 
significant. In the model, if the exchange rate increases by $1 \%$, the vehicle loan interest rate will increase by $1.7 \%$. And $1 \%$ increases in gold and money supply will decrease the vehicle loan interest rate by $0.41 \%$ and $1.48 \%$, respectively. The coefficient of the inflation variable is not statistically significant.

\subsection{Causality Analysis Results}

In the final stage of the study, it was investigated whether there is a causality relationship between variables. For this purpose, Granger Causality Test was used. Table 5 shows the Granger causality test results for Model-1.

Table 5: Causality test results for Model-1

\begin{tabular}{|c|c|c|c|}
\hline Hypothesis & $\mathrm{X}^{2}$ Statistic & Probability & Direction of Causality \\
\hline M2 does not Granger cause rate concumer & 7.414382 & 0.0245 & rate $_{\text {concumer }} \longleftrightarrow$ M2 \\
\hline rate $_{\text {concumer }}$ does not Granger cause M2 & 11.07139 & 0.0039 & \\
\hline gold does not Granger cause rate concumer & 1.783849 & 0.4099 & \\
\hline rate $_{\text {concumer }}$ does not Granger cause gold & 5.942787 & 0.0512 & $\longrightarrow$ gold \\
\hline cpi does not Granger cause rate concumer $_{\text {. }}$ & 8.636556 & 0.0133 & rate $_{\text {concumer }} \longleftrightarrow$ cpi \\
\hline rate $_{\text {concumer }}$ does not Granger cause cpi & 7.352660 & 0.0253 & \\
\hline usd does not Granger cause rate concumer & 5.309210 & 0.0703 & rate $_{\text {concumer }} \longleftarrow$ lnusd \\
\hline rate $_{\text {concumer }}$ does not Granger cause usd & 1.630570 & 0.4425 & \\
\hline
\end{tabular}

According to the results of the causality test in Table 5, it is seen that the consumer loan interest rate and money supply variables have a bidirectional causality relationship at $1 \%$ and $5 \%$ significance levels. On the other hand, there is a bidirectional causality relationship between consumer loan interest rate and inflation variables at the 5\% significance level. According to the results, the unidirectional causality relationship was determined from the consumer loan interest rate to the gold variable at the $10 \%$ significance level. The unidirectional causality relationship from the exchange rate variable to the consumer loan interest rate was determined at a 10\% significance level. Table 6 shows the Granger causality test results for Model-2.

Table 6: Causality test results for Model-2

\begin{tabular}{|c|c|c|c|}
\hline Hypothesis & $\mathrm{X}^{2}$ Statistic & Probability & Direction of Causality \\
\hline M2 does not Granger cause rate mortgage & 0.306712 & 0.8578 & \\
\hline rate $_{\text {mortgage }}$ does not Granger cause M2 & 11.13541 & 0.0038 & rate $_{\text {mortgage }} \longrightarrow \mathrm{M} 2$ \\
\hline gold does not Granger cause rate mortgage & 2.828155 & 0.2431 & rate $_{\text {mortgage }} \longrightarrow$ gold \\
\hline rate $_{\text {mortgage }}$ does not Granger cause gold & 2.612869 & 0.2708 & \\
\hline cpi does not Granger cause rate mortgage & 0.937156 & 0.6259 & rate $_{\text {mortgage }} \longrightarrow$ cpi \\
\hline rate $_{\text {mortgage }}$ does not Granger cause cpi & 2.876794 & 0.2373 & \\
\hline usd does not Granger cause rate mortgage & 13.19501 & 0.0014 & rate $_{\text {mortgage }} \longleftarrow$ usd \\
\hline
\end{tabular}




rate $_{\text {mortgage does not Granger cause usd } \quad 0.209708 \quad 0.9005}$

$\longrightarrow$ means unidirectional causality relationship.

$\succ \quad$ means no causality relationship.

According to the causality test results in Table 6, it is seen that there is a unidirectional relationship at the level of $1 \%$ significance from the mortgage loan interest rate to the money supply variable. There is a causality relationship at the $1 \%$ significance level from the exchange rate variable towards the mortgage loan interest rate. According to the results, no causality relationship was found between the mortgage loan interest rate with gold and inflation variables. Table 7 shows the Granger causality test results for Model-3.

Table 7: Causality test results for Model-3

\begin{tabular}{|c|c|c|c|}
\hline Hypothesis & $\mathrm{X}^{2}$ Statistic & Probability & Direction of Causality \\
\hline M2 does not Granger cause rate vehicle & 7.000012 & 0.0302 & rate $_{\text {vehicle }} \longleftrightarrow$ M2 \\
\hline rate $_{\text {vehicle }}$ does not Granger cause M2 & 4.705418 & 0.0951 & \\
\hline gold does not Granger cause rate vehicle & 8.243643 & 0.0162 & rate $_{\text {vehicle }} \longleftrightarrow$ gold \\
\hline rate $_{\text {vehicle }}$ does not Granger cause gold & 4.967909 & 0.0834 & \\
\hline cpi does not Granger cause rate vehicle & 4.985074 & 0.0827 & rate $_{\text {vehicle }} \longrightarrow$ cpi \\
\hline rate $_{\text {vehicle }}$ does not Granger cause cpi & 7.898394 & 0.0193 & \\
\hline usd does not Granger cause rate $e_{\text {vehicle }}$ & 11.92646 & 0.0026 & rate $_{\text {vehicle }} \longleftarrow$ usd \\
\hline rate $_{\text {vehicle }}$ does not Granger cause usd & 1.487588 & 0.4753 & \\
\hline
\end{tabular}

According to the causality test results in Table 7, the bidirectional causality relationship between the vehicle loan interest rate variable and the money supply, gold, and inflation variables at $5 \%$ and $10 \%$ significance levels was determined. On the other hand, the unidirectional causality relationship from the exchange rate variable to the vehicle loan interest rate is seen at the $1 \%$ significance level.

\section{CONCLUSION AND DISCUSSION}

The study aimed to investigate the relationship between bank loan interest rates and economic indicators such as exchange rate, gold price, money supply and inflation, monthly data between 2009 and 2020 were included in the study. Bank loan interest rates are handled in three different models as consumer loan, mortgage loan and vehicle loan interest rates. In all three models established, loan interest rates took place as dependent variables and macroeconomic variables as independent variables.

The stationarities of the series included in the study were primarily examined by ADF and PP unit root tests, and it was concluded that all variables were stationary at the first difference. Johansen Cointegration Test was conducted to determine the long-term relationship between variables for three 
different models established. The existence of at least one cointegration relationship between variables was observed in all three models.

FMOLS regression, which deals with the second-order asymptotic bias problem arising from serial correlation and endogeneity and which is asymptotically equivalent and effective, was used in order to be informed about the direction and size of long-term relationships of variables with cointegration relationship. In Model-1 and Model-2, where consumer loan interest rate and mortgage loan interest rates are dependent variables, the coefficients of the exchange rate and money supply variables were found to be statistically significant. While the exchange rate variable had a positive effect on bank loan rates, the money supply variable had a negative effect. In Model-3, where vehicle loan interest rate is the dependent variable, unlike other models, it is seen that the coefficient of the gold, as well as the variables of the exchange rate and money supply, is statistically significant.

According to these results, it is seen that the coefficient value of the statistically significant exchange rate variable in all three models is the highest in Model-3. This situation can be explained by the fact that the automotive sector is heavily dependent on foreign countries and imports are made depending on the exchange rate. Most of the studies examining the effect of exchange rate on interest rate in the literature have determined that exchange rate and interest rate are related. An important part of the studies argues that this relationship is positive, Ekinci et al. (2016), Akınc1 and Y1lmaz (2016), Kartal (2019), Vurur (2020) are just a few of them.

The fact that the coefficient of the money supply variable, which has a statistically significant coefficient in the models, turned out to be negative, coincides with the studies in the literature. Some studies concluding that the money supply affects the interest rate negatively; Akıncı and Yilmaz (2016), Kartal (2019).

Comparing the determination coefficient of the models, it is noteworthy that the R2 value of the model in which the vehicle loan interest rate is used is higher than the others. This situation can be interpreted as the macroeconomic dimension of the automotive sector, which is one of the indicators of economic growth and welfare, is higher than other loans. The results are proof that interest rates should be carefully evaluated in terms of affecting investment and consumption expenditures within the economic structure and thus affecting various sectors. In this respect, it is important to follow the interest rate within the framework of economic policies and keep it as low as possible (Kartal, 2019).

The increase in inflation increases the interest rates of banks and so increases the costs of borrowers (Arslan ve Yaprakl1, 2008). However, according to the results obtained from our study, the coefficient of the inflation variable in the model established for all three types of loan interest rates is not statistically significant. These findings obtained between the inflation variable and the bank loan interest rate support the Classical Interest Theory. These findings obtained between the inflation variable and the bank loan interest rate support the classical interest theory. The theory argues that money is neutral in the long run. This means that the real interest rate will be affected by the changes in the amount of money in the short term and will return to its previous level in the long term (Tanrı̈ver ve Yamak, 2015). On the other PAGE 81| Journal of Corporate Governance, Insurance, and Risk Management | 2020, VOL. 7, Series. 2 
hand, the results obtained are in contrast with the Fisher Hypothesis, which states that nominal interest rates and inflation have a positive relationship in the long run (Fisher, 1930). In some of the studies in the literature supports this hypothesis and some of them shows not valid for Turkey. Some of the studies supporting the hypothesis; Şimşek and Kadılar (2006), Alçam (2003) and some of the studies suggesting that it is not valid are Çakmak et al. (2001), Yılancı (2010).

In the last part of the study, Granger causality test was used to investigate causality relationships between variables. In the model in which the consumer loan interest rate is the dependent variable, it is determined that the interest rate and money supply and inflation affect each other mutually. It also appears that the interest rate is a reason for gold prices. In the model in which the mortgage loan interest rate is used, there is a causality relationship between the interest rate and the money supply. Another determination for this model is that gold price, inflation and interest rate do not interact. In the model where the vehicle loan interest rate is included, the interest rate has a mutual relationship with money supply, gold price, and inflation. The only factor that shows similarity in all three models is the relationship determined from exchange rate to interest rates.

The results obtained show that consumer loans, mortgage, and vehicle loans interest rates can be affected differently from economic data. In addition, the results are expected to guide policymakers in applying different interest rates for sectors that have a strong contribution to economic growth with high added value.

\section{REFERENCES}

Akçacı T., Yöntem T. (2011), “The Effect of Varieties of Consumer Credit on Inflation: (2005-2010)”, Finans Politik \& Ekonomik Yorumlar, 48, 558.

Akınc1, M., Yılmaz, Ö. (2016), “The Trade-Off between Inflation and Interest Rate: A Dynamic Least Squares Method for Turkish Economy in the Context of Fisher Hypothesis”, Sosyoekonomi, 24(27), 3356.

Alçam E. (2003), “The Effect of Fisher and testing its validity in Turkey”, Yüksek Lisans Tezi, Marmara Üniversitesi, Sosyal Bilimler Enstitüsü İktisat Anabilim Dalı, Ekonometri Bilim Dalı.

Altunç, Ö. F. (2008), “Türkiye'de Finansal Gelişme ve İktisadi Büyüme Arasındaki Nedenselliğin Ampirik Bir Analizi”, Eskişehir Osmangazi Üniversitesi İİB Dergisi, 3(2), 113-127.

Apaydın Ş. (2018), “Effects of Banking Credits On Economic Growth in Turkey”, Ömer Halisdemir Üniversitesi İktisadi ve İdari Bilimler Fakültesi Dergisi, Vol-Issue: 11(4), 1528. https://doi.org/10.12780/uusbd209 
Arslan I., Yapraklı S. (2008), "Banka Kredileri ve Enflasyon Arasındaki İlişki: Türkiye Üzerine Ekonometrik Bir Analiz (1983-2007)”, Ekonometri ve İstatistik, 7, 88-103.

Asteriou, D., Hall, S. G. (2011), “Applied Econometrics”, Second Edi. Palgrave Macmillan.

Aytaç, D., Sağlam, M. (2014), "Relationship Among Public Deficits Domestic Debt and Interest Rate: Turkey Case”, Eskiş̧ehir Osmangazi Üniversitesi İktisadi ve İdari Bilimler Dergisi, 9(1), 131-148.

Beck T., Levine R. (2004), “Stock Market, Banks and Growth: Panel Evidence”, Journal of Banking and Finance, 28(3) s.423-442. https://doi.org/10.1016/s0378-4266(02)00408-9

Brooks, C. (2002), “Introductory Econometrics For Finance”, Cambridge, Cambridge University Press.

Ceylan, S., Durkaya, M. (2010), “Türkiye'de Kredi Kullanımı- Ekonomik Büyüme İlişkisi”. Atatürk Üniversitesi İ̈BF Dergisi, 24(2), 21-33.

Çakmak, E., Aksu, H., Başar, S., (2002), "Fisher Hipotezinin Türkiye Açısından Değerlendirilmesi: 1989 - 2001”, Atatürk Üniversitesi İktisadi ve İdari Bilimler Dergisi, Cilt: 16, Sayı: 3-4

Dickey, D. A. and Fuller, W. A. (1979), “Distribution of the Estimators for Autoregressive Time Series with a Unit Root”, Journal of the American Statistical Association, 74(366a), 427-431. https://doi.org/10.1080/01621459.1979.10482531

Duican E. R., Pop A. (2015), “The Implications Of Credit Activity On Economic Growth in Romania”. Procedia Economics And Finance, 30, 195-201. https://doi.org/10.1016/s2212-5671(15)01286-1

Ekinci, E. B. M., Alhan, A., Ergör, Z. B. (2016), “Nonparametric Regression Analysis: Examining the Relationship Between Interest Rate, Inflation and Exchange Rate”, Bankacılık ve Sigortacilık Araştırmaları Dergisi, 2(9), 28-37.

Fisher, I., (1930), “TheTheory Of Interest”, New York, The Macmillan Company.

Granger, C.W.J. (1988), "Some Recent Developments in a Concept of Causality”, Journal of Econometrics, 39(1-2), 199-211. https://doi.org/10.1016/0304-4076(88)90045-0 
Güven, S. (2002), “Türkiye'de Banka Kredileri ve Büyüme İlişkisi”, İktisat, İşletme ve Finans, 17(197), s. 88-100. https://doi.org/10.3848/iif.2002.197.7452.

Hansen, B.E. (1992), “Tests for Parameter Instability in Regressions with I(1) Processes”, Journal of Business and Economic Statistics, 10(3), 321-335. https://doi.org/10.1080/07350015.1992.10509908

Ibicioglu M., Karan B.M. (2009), “The Effect of Interest Rates on Consumer Credit in Turkey”, BDDK Bankacılık ve Finansal Piyasalar Cilt:3, Sayı:2.

Johansen, S. (1988), “Statistical analysis of co-integrating vectors”, Journal of Economic Dynamics and Control, 12(2-3), 231-254. https://doi.org/10.1016/0165-1889(88)90041-3

Johansen, S. and Juselius, K. (1990), "Maximum Likelihood Estimation And Inference On Cointegration: With Application To The Demand For Money”, Oxford Bulletin of Economics and Statistics, 52(2),169-210. https://doi.org/10.1111/j.1468-0084.1990.mp52002003.x

Kar, M., \& Pentecost, E. J. (2000), “The Direction of Causality Between Financial Development and Economic Growth in Turkey: Further Evidence. Economic Research Paper”, Department of Economics, Loughborough University (00/27), 1-21.

Kartal T. M. (2019), “Determination of Influencing Factors of Credit Interest Rates in Turkey: An Analysis with MARS Method”, Bankacılar Dergisi, Sayı 108.

Kılıç F., Torun M. (2018), "The Impact of Personal Loans on Inflatıon: The Case of Turkey", Cilt/Volume: 16 Say1/Issue: 1 Mart/March 2018 ss./pp. 18-40. http://dx.doi.org/10.11611/yead.386270

Korkmaz, S. (2015), “Impact of Bank Credits on Economic Growth and Inflation”, Journal of Applied Finance\&Banking, 5(1):57-69.

Levine R, Zervos S. (1998), “Stock Markets, Banks and Economic Growth”, The American Economic Review, 88(3), s.537-558.

McCaig B., Stengos T. (2005), "Financial Intermediation And Growth: Some Robustness Results”, Economics Letters, 88(3), 306-312. https://doi.org/10.1016/j.econlet.2004.12.031

Mercan, M. (2013), “Kredi Hacmindeki Değişimlerin Ekonomik Büyümeye Etkisi: Türkiye Ekonomisi İçin Sınır Testi Yaklaşımı”. Bankacılar Dergisi (84), 54-71.

PAGE 84| Journal of Corporate Governance, Insurance, and Risk Management | 2020, VOL. 7, Series. 2 
Obeng, S. K., Sakyi, D. (2017), “Macroeconomic Determinants of Interest Rate Spreads in Ghana”, African Journal of Economic and Management Studies, 8(1), 76-88. https://doi.org/10.1108/ajems-122015-0143

Ozen E., Ozdemir L., Simon G. (2020), “The Relationship between the Exchange Rate, Interest Rate and Inflation: The Case of Turkey”, Scientific Annals of Economics and Business 67 (2), 259-275. https://doi.org/10.47743/saeb-2020-0014

Pagano, M., Pica G. (2012), "Finance and Employment”, Economic Policy, 27(69), 5-55. https://doi.org/10.1111/j.1468-0327.2011.00276.x

Pehlivan, P., Demirlioğlu, L., Yurtseven, H. (2017), “Türkiye'de Bankacılık Faaliyetleri ile Ekonomik Büyüme Arasındaki İlişkinin Analizi”, V. Anadolu International Conference in Economics (s. 1-14).

Peker, O. ve Canbazoğlu, B. (2011), "Processing of Bank Lending Channel in Turkey: An Empirical Analysis”, Yönetim ve Ekonomi Dergisi, 18(2):127-143.

Phillips, P. ve Hansen, B. (1990), “Statistical Inference in Instrumental Variables Regression with I(1) Processes”, Review of Economic Studies, 57(1), 99-125. https://doi.org/10.2307/2297545

Phillips, P. ve Perron, P. (1988), “Testing for a Unit Root in Time Series Regression”, Biometrika, 75(2), 335-346. https://doi.org/10.1093/biomet/75.2.335

Sever, E., Han, V. (2015), “Türkiye'de Reel Kesim ile Bankacılık Kesimi Arasındaki İlişkinin Analizi: Sektörel Bir Yaklaşım”, Aksaray Üniversitesi İ̈BF Dergisi, 7(2), 1-9.

Şimşek, M. ve Kadılar, C., (2006), “The Analysis of Fisher Effect Using Turkish Data”, Doğuş Üniversitesi Dergisi, 7(1), 99-111. https://doi.org/10.31671/dogus.2019.265

Tanrı̈ver B., Yamak N. (2015), “Analysis of Nominal Interest Rate-General Price Level Relationship Within the Framework of Gibson Paradox”, Maliye Dergisi, 168.

Tuna, K., Bektaş, H. (2013), “Kredi Hacminin Ekonomik Büyüme Üzerindeki Rolünün İncelenmesi: Türkiye Örneği”, Finansal Araştırmalar ve Çalışmalar Dergisi, 5(9), 139-150. 
Tunalı H., Erönal Yıldırım Y. (2016), "Relation Between Inflation and Interest Rates: Validity of Fisher Effect In Turkey”, Süleyman Demirel Üniversitesi İktisadi ve İdari Bilimler Fakültesi Dergisi, C.21, S.4, s.1415-1431.

Turgut A., Ertay I. H. (2016), "Effects of Banking Sector on Economic Growth: Casual Analysis on Turkey”, Aksaray Üniversitesi İktisadi ve İdari Bilimler Fakültesi Dergisi, 8 (4), 114-128.

Vurur, N. S., Özen, E. (2013), “Türkiye’de Mevduat Banka Kredisi ve Ekonomik Büyüme İlişkisinin İncelenmesi”, Uşak Üniversitesi Sosyal Bilimler Dergisi, 6(3), 117131. https://doi.org/10.12780/uusbd209

Vurur, N.S. (2020), "Relationship Between Interest Rates, Exchange Rate and Investor Sentiment in Turkey”, Uncertainty and Challenges in Contemporary Economic Behaviour, 127-138. https://doi.org/10.1108/978-1-80043-095-220201010

$\underline{\text { www.tcmb.gov.tr }}$

Yağcılar Göçmen G., (2011), “Türk Bankacılık Sektörünün Rekabet Yapısının Analizi”, BDDK Kitapları, No: 10, Ankara.

Yılanc1, V. (2010), "Fisher Hipotezinin Türkiye için Sınanması: Doğrusal Olmayan Eşbütünleşme Analizi”, Atatürk Üniversitesi İ̈BF Dergisi, Cilt 23, say1 4.

Y1lmaz, S., İskenderoğlu, Ö., Önal, Y. B. (2007), "Finansal Gelişme ve Ekonomik Büyüme Arasındaki İlişkinin Araştırılması”, Ç.Ü. Sosyal Bilimler Enstitüsü Dergisi, 16(2), s. 311-326. 